\title{
How Universities Entrust Digital Literacy to Improve Student Learning Outcomes During the COVID-19 Disruption
}

\author{
Abd. Basir1, Kamaliah2 ${ }^{2}$, Arman Harahap ${ }^{3}$, Ahmad Fauzi ${ }^{4}$, Budi Karyanto ${ }^{5}$ \\ 1 Universitas Islam Negeri (UIN) Antasari Banjarmasin, Indonesia \\ 2SMA Negeri 2 Martapura, Kalimantan Selatan, Indonesia \\ ${ }^{3}$ Universitas Labuhanbatu, Indonesia \\ ${ }^{4}$ Kementrian Desa BPSDMPMDTT (Badan Pengembangan Sumber Daya Manusia Dan \\ Pemberdayaan Masyarakat Desa Daerah Tertinggal dan Transmigrasi, Indonesia \\ ${ }^{5}$ Sekolah Tinggi Ilmu Ekonomi Bisma Lepisi, Indonesia \\ kamaliahkamaliah00@gmail.com
}

ABSTRACT

Since the policy of sending students home to study as a result of responding to the dangers of the pandemic, universities around the world have increasingly trusted distance learning solutions. The solution

ARTICLE INFO

Article history:

Received

October 04, 2020

Revised

July 21, 2021

Accepted

July 25, 2021 was to rely on digital literacy to continue and improve student learning outcomes during the COVID-19 disruption. For this reason, the researchers have proven it through analytical efforts and in-depth studies in several international publications. In short, the researchers examined each piece of evidence with a phenomenological approach to get answers to research questions that are among other things, involve a data coding system, critical evaluation, and drawing of valid and reliable final results. The data discussion concludes that world universities believe that digital technology that was increasingly trending can become a learning innovation even though the world will continue to hit global education. Hence, the researchers hope that these findings should support other studies in the future.

Keywords: Digital Literacy, Learning Outcomes, Entrust Digital Literacy

How to cite Abd. Basir., et al (2021). How Universities Entrust Digital Literacy to Improve Student Learning Outcomes During the COVID-19 Disruption. Jurnal Iqra': Kajian Ilmu Pendidikan, 6(1). 235-246.

https://doi.org/10.25217/ji.v6i1.1146

Journal Homepage http://journal.iaimnumetrolampung.ac.id/index.php/ji/

This is an open access article under the CC BY SA license

https://creativecommons.org/licenses/by-sa/4.0/

\section{INTRODUCTION}

Coronavirus is a coronavirus infection disease that WHO has confirmed originated from Wuhan, China. (Lancet, 2020; Care and Relief, 2020). This disease can be transmitted effectively and can cause the transmission to the people around him, and people who have a history of certain illnesses can be at risk of death. (Boccia et al., 2020). The spread of infection with the number shows an increase in Indonesia, making standards or arrangements approved in various regions with the ultimate goal of limiting its spread. The new guidelines that have been given are a new trend for individuals. They have to wear masks, bring hand sanitizer, stay away from crowds, and so on must be resolved. (Scerri and Grech, 2020). The school area has also undergone an adjustment to education and learning, which was initially face-to-face 
and personal in classrooms or meetings and transferred to the network. Then automatically, educators and students believe in the benefits of electronic media for an indefinite period. (Williamson et al., 2020). Because the distance learning model has no end, this online method has become a habit, teachers and students can feel the benefits of digital literacy. Various associations can utilize sophisticated media, such as longdistance associations or teleconferencing and Zooming schools. (Hacker et al., 2020).

As a result of the increasingly widespread Coronavirus, the government must be aware that the transmission is high-speed, and there is no authorized treatment. (Jadhav et al., 2020). Finally, taking policy action, all activities are carried out from home with the following conditions: online or distance learning, learning exercises, and work shifts. Recognition of new students is recognized by public government authorities as long as it does not harm themselves, society, and the state. During the COVID-19 pandemic, every individual, especially students, needs to dominate further education. (Mikolai et al., 2020). Proficiency is the capacity in a person to write and read carefully through digital tools from mechanical skills to improve student learning. Improve mind execution as it is commonly used for reading and writing exercises. These include the benefits of digital that must be hurt by students and universities. (Watermeyer et al., 2021).

With national policies responding to the current pandemic in every country, students worldwide trust this sophisticated data and intelligence literacy as a necessity. (Sakib et al., 2020). The exemplary media literacy will increase the turn of events and changes in academic activity elements that can impact achieving results in the long term. With the Covid-19 pandemic, changes in circumstances are felt in all areas in the public arena, one of which is in the teaching area at all levels in Indonesia. This turned into a need for instructive operational recognition for learning. (Collier et al., 2021). It resembles a hurricane that destroys human life when the COVID-19 infection appears-seeing the victims of COVID-19 fall unexpectedly in the millions. Unexpectedly, the analyst as a whole needs to find an improvement in the method of conducting learning in higher education. (Cicha et al., 2021). In the modern century, COVID-19 has become a human being who has to move away from each other physically, which has never happened before, and no one knows for sure when it will end, especially for Indonesia, which is still surprising the rest of the world's population.

Jena, (2020) said that the impact of the COVID-19 pandemic on the education of countries in Asia is not only in education but in other sectors. The lower working class began to scream at the lack of livelihood and job misfortune. It is impossible to do many exercises together. Higher education authorities utilize digital media and maintain social distance and actual distance to reduce the virus flexibility space in the area. (Megahed and Ghoneim, 2020). It is appropriate to stay at home, as long as students are most likely aware of the benefits of digital media. All learning is done from home as much as can be done to limit actual connections. (Zulman and Verghese, 2021). For students and students, e-learning, web-based learning, or home learning. These alternatives are entrusted to digital technology, which is ready to revolutionize the previously known learning system. (Uebernickel and Thong, 2021).

For this reason, universities provide online strategies for all education and learning units. (Moore and Greenland, 2017). The need for remote adaptation dominates advanced innovation and information technology. Complaints about the implementation of learning activities arise from the guardians of students. They have a dual capacity: to replace lecturers who follow student learning and record all student 
learning actions by being photographers and cameramen. (Luna, 2020). Also, the assignments that students get every day. The restrained force allows this whole thing to be completed. Everyone has to figure out how to handle data advancement and advanced through distance learning. There are no exceptions for supervisors and educators, students, workers, and guardians of education/school units. Students are constrained to reflect on innovation by conditions. (Bozkurt et al., 2020). However, they need to get their college-level advancement and knick-knapping skills on the positive side. This is a place where the importance of mechanical skills in contemporary society is evident. Innovative information that sometime before should have been obtained.

The computerized way of innovation has also been a source of effect in university education for a long time. (Iaccarino et al., 2020). Current teaching and learning programs do not continue as face-to-face events in the classroom but can also be completed online. Elective reference assets may not only be reference sources from books, digital materials, and the web. (Putra et al., 2020; Hendriarto et al., 2021). The developments in people's way of life and behavior, which can be inferred from their impact, are known as hours of distraction. We are currently in the era of Industrial Revolution 4.0, which demands computerized innovation to dominate. It is not a decision at all anymore, but a necessity. The computerized system since the center of the 1960s is the starting point for the advancement of hardware, data innovations, and the production of robotized machines. From that point forward, advancements identifying with digital tools have been advancing amazingly quickly. The rise of the cell organization and the Internet organization, trailed by a small Internet organization, empowered it a lot faster than anybody might have suspected already to disperse data and data. Email, news access, amusement, everything happens in no time flat-social outcomes: individuals, data, and media. (Ahmad and Murad, 2020).

Considering the anticipation of this pandemic situation, universities and governments in global education have switched to distance learning with the help of digital tools. The impact of the disruption to the Covid-19 outbreak will not become a significant obstacle to the survival of universities. Therefore, we try to understand what and how the university believes in digital learning innovation. (Susilawati and Supriyatno, 2020).

\section{METHOD}

The researchers have proven our hypothesis through this qualitative method by reviewing some of the previous findings with a coding system and in-depth analysis of each data. The researchers conducted an online search on Google Apps, specifically on articles published between 2010 and 2021, then analyzed them very critically to ensure that our findings are very close to the validity and reliability of answering the research questions. In searching the data, the researchers used keywords, which included "university studies," "digital literacy," "students learning," "learning outcomes." the researchers followed the guidelines for reviewing education with qualitative methods recommended by experts, mainly research and development studies. (Ip et al., 2012; Holliday, 2010; Sgier, 2012).

\section{RESULT AND DISCUSSION}

Since Covid-19 hit high education, website-based learning is like a panacea when all college activities are disrupted. This is due to the impact of the policy to stop the Covid-19 outbreak, which suddenly led to the outbreak of a deadly disease known as a pandemic caused by the SARS-CoV-2 coronavirus, which shocked the world. 
(Terranova-Barberio et al., 2020). Many academic organizations, hesitant to change their traditional way of teaching, have little choice but to switch entirely to web-based learning. The essay considers the importance of online learning and research of elearning modalities during times of emergency. The growth of EdTech start-ups during the hours of epidemics and catastrophic events has also been made clear. Many similar studies have also been carried out to respond to the outbreak, but learning still has to go on. The solution is in digital literacy tools. (Zulkarnain et al., 2020).

As a result of the impact of the COVID-19 pandemic on the review of data and work by higher education management, education, work, and life transformation activities must continue, namely with the addition of technology media. (Krishnasamy et al., 2020). What else can you say, the COVID-19 pandemic has forced several organizations to undergo a massive transformation. This solution provides an overall knowledge, using a data framework and a creative perspective, of many of the critical issues and fundamental complexities that affect organizations and society. The perspectives of 12 welcomed professional topics are organized and examined to identify each of the following understandable aspects: internet learning, computerized technology, handcrafted reasoning, managerial data, social cooperation, network security, considerable information, blockchain, security, innovation, and processes portable. The findings and similarity of the study were also carried out by Radanliev et al., (2020) where COVID-19 has taught humanity. Since the pandemic, humans, especially academics, are increasingly severe about solutions in the style of digital technology. This is the beginning of the collective world university trusting technology solutions during the increasingly orderly pandemic and providing better results.

Goicoechea et al., (2020) noted that the skills of advanced students and further education during the COVID-19 lockdown were greatly helped by the digital tool. During the internationally imposed lockdowns for the COVID-19 pandemic, a worldwide instructive framework must deal with the many troublesome changes. The point of the exam is to introduce an immediate investigation of three countries' continuing education organizations (Spain, Italy, and Ecuador), outlining how they are dealing with the state of lockdowns around the world. The results indicate the need to improve fundamental aspects such as advanced skills of instructors, customizable learning points, communication between colleges and students, and educational procedures.

Qadir and Al-Fuqaha, (2020) a student guide on how to progress in engineering education during and after COVID-19. The worldwide pandemic has disrupted educational activities, with colleges completely closing in many parts of the world and students and staff turning to remote learning. The primary commitment of this paper is to make sense: the researchers present a mix of excellent test writing about viable student learning in public, online, and upset settings. Towards the end of the paper, they also present a conversation about essential issues identified with distance teaching and online training, for example, value assurance and maintenance of lab work for engineers in digital literacy-assisted learning settings during a pandemic. (Aydin and Erol, 2021).

The disruption of the Coronavirus pandemic on tertiary education and learning and capacity building through student assessments of web-based learning meetings in Hong Kong was essential. (Yao et al., 2021). The COVID-19 pandemic has limited the teaching and learning of the internet to design an essential guide in universal continuing education. This study examines how students in Hong Kong assessed their web-based learning during the pandemic, including factors affecting their

\section{8}


computerized learning. It was tracked that most of the respondents were disappointed with the meeting and the adequacy of their online learning. Discovery empowers college pioneers and teachers to explore different modes of course delivery to help students become wise pioneers with 21st-century capabilities. (Myers and Berkowicz, 2015; Soni, 2020).

Worldwide Impact of E-getting the hang of at COVID 19. The present study emphasizes the global impact of the e-learning measure during COVID 19. The globe is utterly susceptible to data developments throughout these crises. This may be referred to as having an increased quantity of online courses, gatherings, gatherings, and so forth. The present research offers knowledge into the interplay of electronic learning and its advantages with the refreshing variation of its usage.

The disruption of the Coronavirus pandemic on tertiary education and learning and capacity building through student assessments of web-based learning meetings in Hong Kong was essential. (Yao et al., 2021). The COVID-19 pandemic has limited the teaching and learning of the internet to design an essential guide in universal continuing education. This study examines how students in Hong Kong assessed their web-based learning during the pandemic, including factors affecting their computerized learning. It was tracked that most of the respondents were disappointed with the meeting and the adequacy of their online learning. Discovery empowers college pioneers and teachers to explore different modes of course delivery to help students become wise pioneers with 21st-century capabilities. (Myers and Berkowicz, 2015).

Bączek et al., (2021) said that students' views on internet pick-up during the COVID-19 pandemic study investigation of Polish clinical undergraduates. The pandemic has disrupted education in various organizations, especially in clinical schools. Electronic learning (e-learning) has become a central technique for broadcasting educational programs during a pandemic. After two months of only webbased learning, a study was led to explore this view of learning among clinical students. Most respondents chose the lack of cooperation with patients and particular problems with information technology equipment as the main obstacles. (He et al., 2021).

The last article the researchers reviewed was from Adarkwah, (2021) which states that it is not against internet education, but what it might say about us involves ICT in post-Covid-19 Ghana. Internet learning is hailed as a fundamental force in democratizing teaching. This method opens instructions for people with limited access based on the actual topography, status, or disturbance. There has been a disproportionate spread of ICT acceptance among different populations, families, and spaces since the network. A similar study was also reported by Adedoyin and Soykan, (2020). They said that the Covid-19 pandemic and online lectures were challenges that could be overcome with highly literate digital technology solutions.

Student proficiency in higher education is necessary for the world of learning in any country. (Adeoye et al., 2020). So, during the Covid-19 pandemic, a national policy made new arrangements so that all learning and teaching tasks are not included in face-to-face anymore but are carried out using advanced media, namely digital technology assistance, a collection of applications to support distance learning. In computerized university proficiency, students do not need to visit the destination in person to get data. (Charissi et al., 2020). This means they can find data faster and learn faster. The advantages of advanced skills include setting aside time and money. During the Covid-19 pandemic, all individuals can do all exercises at home and limit exercise 
outside the home. Cash reserve funds can be used if students use computerized media in making online purchases. Many guidance offices are available for lecturers and students who take coaching after school by utilizing computerized capabilities. (Dong et al., 2020). Advanced universities currently have many data sources that can be used to reference when knowing what they need. The worldwide solution is distance learning with the help of digital devices. (Jena, 2020; Aslan et al., 2020; Sudarmo et al., 2021; Manullang et al., 2021). In times of pandemic, reliable state-of-the-art data will make individuals in the university environment consistently get new data. The university empowers students to make better choices because it allows them to choose digital tools and their literacy skills to view, study, and analyze them. (Hanbidge et al., 2018). This has become a necessity for the Indonesian people in any case during the current pandemic because all data will always be linked in the media. With computerization skills, students at higher levels can help with work, especially computer technology. This is a separate task for students who want to research the current pandemic. (Ashrafzadeh and Sayadian, 2015; Suroso et al., 2021). Today, many literacy media are used today, such as financial managers and the general public, to involve self-task completion. This solution is essential for universities to trust students to complete assignments and innovative ways of learning and maintain lecture excellence and increase results and relaxation in times of pandemic emergency. (Guo and Huang, 2021).

Besser et al., (2020) said that the information and abilities possessed by advanced university students' skills in finding, evaluating, utilizing, creating, and utilizing computerized media, embedding devices and organizations in such a way as to enhance correspondence and cooperation in daily life that are solid, intelligent, wise, careful, precise. And valid programming. (Miller, 2021). Advanced skills can also convey substance/information with intellectual and exceptional capacities by utilizing digital tools. The definition of digital education is progressively closely related to specific information about data access, selection, recognition, and dissemination. (Pappas and Giannakos, 2021). Indonesia's mechanical development cannot be separated from the foundation of accessibility through a web framework, which, since the fourth-generation network came to power in 2010 and became 4G LTE in 2013, began to proliferate (Bento, 2016).

Mobile organizations strongly support university learning, and the use of web innovation is extensive and inevitable by broadband web networks. (Jones et al., 2010). To help develop their organizations, more and more universities are making online applications. Sites are more dynamic and robust but no longer static. Market spots and webshops began to appear. Innovative fields are no less agile in leveraging new worldclass organizations. Our organization started studying exchange on the web. The increase in online cruiser taxi applications logically affects the organization directly. The college tradition is starting to shift to the online way. (Dhawan, 2020). The general practice of society began to include online exams, online purchases, online exchanges, and shocking online dinner requests. The effect is now starting to be seen; campus organizations are starting to start due to the proliferation of web stores that offer internet connection services that are increasingly cheap and compete for services to the public. (Akram et al., 2020). This adds to the confidence of universities and the government why learning is slowly being shifted to the virtual way with the help of digital applications. (Pregowska et al., 2021).

This finding is interesting because in substantiating these findings, the researchers examine the findings from databases of high-impact publications such as Wely, Taylor 
\& Francis, Eric publications, and several internationally renowned publications. Then the researchers focus on the latest data findings that the researchers are targeting between 2010 and 2021. So based on publications by authors from all over the world who have proven their in-depth knowledge and well-known scientific reputation, the researchers believe that this data exposure is very valid and reliable.

Leaders in higher education discuss how digital technology skills are essential for the development of student achievement and employee productivity in contemporary academic society (Davies et al., 2017). Because of the workings and convenience of these digital tools, they can provide more profound knowledge or perspectives that influence students' thinking and learning at the higher education level. When they are, the academic community must see things differently, the way automation works and is trendy (Siemens, 2013). Students become long-life learners; literacy tools are up-andcoming compared to traditional learning methods. It provides academics with vital and intellectual skills throughout the ages. With digital materials, educators help students use work skills and critical thinking to assess the quality of digital content lesson content, which helps students process and communicate more effectively and productively.

Now all are asking how digital literacy can potentially benefit universities? So the answer is if students who acquire digital literacy as an essential part of their studies practically have more efficient abilities and graduate because more than $90 \%$ of academic jobs are proven to have passed requiring adequate digital skills. (Van Deursen and Van Dijk, 2014). Becoming excellent at digital skills implies that students acquire technical knowledge, learn the rules of writing systems such as copyright and are free from plagiarism, are aware of how students obtain information in virtual ways while engaging in social networking, and learning academic integrity. In today's higher academic world, digital literacy is above all, and it is a significant component. (Koltay, 2011). The need to help college students become students of all times is possible because of digital literacy. This provides the academic community with essential skills and academic qualifications they can rely on. Examining Bloom's taxonomy, digital literacy can awaken students in all subject curricula from the description of Bloom's University of South California. (Maphosa and Bhebhe, 2019). Long before, Paul Gilster coined the term 'digital literacy as 'the capacity to understand and utilize digital information. (Lankshear and Knobel, 2008). Many teaching initiatives at UK universities have examined elements of digital literacy, leading to reliable guidance.

Besides the advantages, this review of our publications also has limitations. Limitations include our reliance on secondary data to answer the problems of our study. The researchers should have obtained other data directly with university visits in several countries that have been proven successful using digital literacy in breaking down the progress of student learning outcomes and employee performance, including lecturers and the academic community. However, we cannot do all of this when the researchers carry out this study if Indonesia has implemented restrictions on the movement of citizens in response to the pandemic. So our solution relies on finding data from publications that the researchers search electronically.

\section{CONCLUSION}

The researchers close this section with the conclusion of a series of research studies that aim to gain a strong understanding of how universities entrust digital literacy to improve student learning outcomes during the COVID-19 disruption. We are very confident that we are reviewing and getting answers to the questions of this study 
where on average, the articles we have reviewed have added a new understanding of how the majority of the world's universities have believed that Covid-19 solutions and responses have been successfully carried out through digital applications to improve learning outcomes during a pandemic. Belief in digital technology is not without reason how the field evidence data that technological capabilities revolutionize and innovate learning and evaluation. They continue to recommend that computerized digital tools continue to be pursued as a solution option even after the pandemic ends.

\section{ACKNOWLEDGEMENT}

The authors received a lot of support from colleagues and academic support from preparation to the completion for that reason we would like appreciate for those people. Similarly to Minister of Research and Technology for sponsorship support in finance so that the paper has been done so far entitles "How University Truth the Digital Tools to Improve Students Learning Outcomes During Pandemic Covid-19 Disruption"

\section{AUTHOR CONTRIBUTION STATEMENT}

The authors have work in a share part to Finnish this project. The researchers have agree that there is nothing conflict in this paper completion so that we are agree to a share contribution to whole part of completion each author work cooperatively.

\section{REFERENCES}

Adarkwah, M.A., 2021. "I'm not against online teaching, but what about us?": ICT in Ghana post Covid-19. Educ. Inf. Technol. 26, 1665-1685. https:// doi.org/10.1007/s10639-020-10331-z

Adedoyin, O.B., Soykan, E., 2020. Covid-19 pandemic and online learning: the challenges and opportunities. Interact. Learn. Environ. 1-13. https://doi.org/10.1080/10494820.2020.1813180

Adeoye, I.A., Adanikin, A.F., Adanikin, A., 2020. COVID-19 and E-learning: Nigeria tertiary education system experience. Google Scholar

Ahmad, A.R., Murad, H.R., 2020. The impact of social media on panic during the COVID-19 pandemic in Iraqi Kurdistan: online questionnaire study. J. Med. Internet Res. 22, e19556. https:// doi.org/10.2196/19556

Akram, M., Shahzadi, G., Peng, X., 2020. Extension of Einstein geometric operators to multi-attribute decision making under q-rung orthopair fuzzy information. Granul. Comput. 1-17. https:// doi.org/10.1007/s41066-020-00233-3

Ashrafzadeh, A., Sayadian, S., 2015. University instructors' concerns and perceptions of technology integration. Comput. Hum. Behav. 49, 62-73. https://doi.org/10.1016/j.chb.2015.01.071

Aslan, A., Silvia, S., Nugroho, B.S., Ramli, M., Rusiadi, R., 2020. Teacher's leadership teaching strategy supporting student learning during the covid-19 disruption. Nidhomul Haq J. Manaj. Pendidik. Islam 5, 321-333. https:// doi.org/10.31538/ndh.v5i3.984

Aydin, E., Erol, S., 2021. The views of Turkish language teachers on distance education and digital literacy during covid-19 pandemic. Int. J. Educ. Lit. Stud. 9, 60-71.

Bączek, M., Zagańczyk-Bączek, M., Szpringer, M., Jaroszyński, A., WożakowskaKap \lon, B., 2021. Students' perception of online learning during the COVID-19 pandemic: a survey study of Polish medical students. Medicine (Baltimore) 100. 
Bento, N., 2016. Calling for change? Innovation, diffusion, and the energy impacts of global mobile telephony. Energy Res. Soc. Sci. 21, 84-100. https://doi.org/10.1016/j.erss.2016.06.016

Besser, A., Flett, G.L., Zeigler-Hill, V., 2020. Adaptability to a sudden transition to online learning during the COVID-19 pandemic: Understanding the challenges for students. Scholarsh. Teach. Learn. Psychol. https:/ / psycnet.apa.org/doi/10.1037/st10000198

Boccia, S., Ricciardi, W., Ioannidis, J.P., 2020. What other countries can learn from Italy during the COVID-19 pandemic. JAMA Intern. Med. 180, 927-928.

Bozkurt, A., Jung, I., Xiao, J., Vladimirschi, V., Schuwer, R., Egorov, G., Lambert, S., AlFreih, M., Pete, J., Olcott Jr, D., 2020. A global outlook to the interruption of education due to COVID-19 pandemic: Navigating in a time of uncertainty and crisis. Asian J. Distance Educ. 15, 1-126. Google Scholar

Care, P., Relief, P., 2020. Palliative care and the COVID-19 pandemic.

Charissi, A., Tympa, E., Karavida, V., 2020. Impact of the covid-19 disruption on university students'perceptions and behavior. Eur. J. Educ. Stud. 7. http://dx.doi.org/10.46827/ejes.v7i11.3348

Cicha, K., Rizun, M., Rutecka, P., Strzelecki, A., 2021. COVID-19 and higher education: first-year students' expectations toward d i stance learning. Sustainability 13, 1889. https:// doi.org/10.3390/su13041889

Collier, D., Fitzpatrick, D., Dell, M., Snideman, S., Marsicano, C., Kelchen, R., 2021. We Want You Back: Uncovering the Influences on In-Person Instructional Operations in Fall 2020. Google Scholar

Davies, S., Mullan, J., Feldman, P., 2017. Rebooting learning for the digital age: What next for technology-enhanced higher education? Higher Education Policy Institute Oxford.

Dhawan, S., 2020. Online learning: A panacea in the time of COVID-19 crisis. J. Educ. Technol. Syst. 49, 5-22. https:/ / doi.org/10.1177\%2F0047239520934018

Dong, C., Cao, S., Li, H., 2020. Young children's online learning during COVID-19 pandemic: Chinese parents' beliefs and attitudes. Child. Youth Serv. Rev. 118, 105440. https://doi.org/10.1016/j.childyouth.2020.105440

Goicoechea, M., Cámara, L.A.S., Macías, N., de Morales, A.M., Rojas, Á.G., Bascuñana, A., Arroyo, D., Vega, A., Abad, S., Verde, E., 2020. COVID-19: clinical course and outcomes of 36 hemodialysis patients in Spain. Kidney Int. 98, 27-34.

Guo, J., Huang, J., 2021. Information literacy education during the pandemic: The cases of academic libraries in Chinese top universities. J. Acad. Librariansh. 47, 102363. https://doi.org/10.1016/j.acalib.2021.102363

Hacker, J., vom Brocke, J., Handali, J., Otto, M., Schneider, J., 2020. Virtually in this together-how web-conferencing systems enabled a new virtual togetherness during the COVID-19 crisis. Eur. J. Inf. Syst. 29, 563-584. https://doi.org/10.1080/0960085X.2020.1814680

Hanbidge, A.S., Tin, T., Sanderson, N., 2018. Information Literacy Skills on the Go: Mobile Learning Innovation. J. Inf. Lit. 12.

He, W., Zhang, Z.J., Li, W., 2021. Information technology solutions, challenges, and suggestions for tackling the COVID-19 pandemic. Int. J. Inf. Manag. 57, 102287. https:/ / doi.org/10.1016/j.ijinfomgt.2020.102287

Hendriarto, P., Aslan, A., Mardhiah, Sholihin, R., Wahyudin, 2021. The Relevance of Inquiry-Based Learning in Basic Reading Skills Exercises for Improving Student 
Learning Outcomes in Madrasah Ibtidaiyah. -Tajdid J. Pendidik. Dan Pemikir. Islam 5, 28-41. https:/ / doi.org/10.24127/att.v5i01.1473

Holliday, A., 2010. Analysing qualitative data. Contin. Companion Res. Methods Appl. Linguist. 98-110.

Iaccarino, G., Grassi, G., Borghi, C., Ferri, C., Salvetti, M., Volpe, M., 2020. Age and multimorbidity predict death among COVID-19 patients: results of the SARSRAS study of the Italian Society of Hypertension. Hypertension 76, 366-372. https:// doi.org/10.1161/HYPERTENSIONAHA.120.15324

Ip, S., Hadar, N., Keefe, S., Parkin, C., Iovin, R., Balk, E.M., Lau, J., 2012. A Web-based archive of systematic review data. Syst. Rev. 1, 1-7. https:/ / doi.org/10.1186/2046-4053-1-15

Jadhav, V.R., Bagul, T.D., Aswale, S.R., 2020. COVID-19 era: students' role to look at problems in education system during lockdown issues in Maharashtra, India. Int. J. Res. Rev. 7, 328-331. Google Scholar

Jena, P.K., 2020a. Impact of pandemic COVID-19 on education in India. Int. J. Curr. Res. IJCR 12.

Jena, P.K., 2020b. Online learning during lockdown period for covid-19 in India. Int. J. Multidiscip. Educ. Res. IJMER 9. Google Scholar

Jones, C., Ramanau, R., Cross, S., Healing, G., 2010. Net generation or Digital Natives: Is there a distinct new generation entering university? Comput. Educ. 54, 722732. https:// doi.org/10.1016/j.compedu.2009.09.022

Koltay, T., 2011. The media and the literacies: Media literacy, information literacy, digital literacy. Media Cult. Soc. 33, 211-221.

Krishnasamy, V.P., Hallowell, B.D., Ko, J.Y., Board, A., Hartnett, K.P., Salvatore, P.P., Danielson, M., Kite-Powell, A., Twentyman, E., Kim, L., 2020. Update: characteristics of a nationwide outbreak of e-cigarette, or vaping, product useassociated lung injury-United States, August 2019-January 2020. Morb. Mortal. Wkly. Rep. 69, 90. Google Scholar

Lancet, T., 2020. Palliative care and the COVID-19 pandemic. Lancet Lond. Engl. 395, 1168.

Lankshear, C., Knobel, M., 2008. Digital Literacies: Concepts, Policies and Practices. Peter Lang. Google Scholar

Luna, A., 2020. JSU enrollment increases by 2.4 percent for fall semester.

Manullang, S.O., Mardani, M., Aslan, A., 2021. The Effectiveness of Al-Quran Memorization Methods for Millennials Santri During Covid-19 in Indonesia. Nazhruna J. Pendidik. Islam 4, 195-207. https://doi.org/10.31538/nzh.v4i2.1334

Maphosa, C., Bhebhe, S., 2019. Digital literacy: A must for open distance and e-learning (ODEL) students. Eur. J. Educ. Stud.

Megahed, N.A., Ghoneim, E.M., 2020. Antivirus-built environment: Lessons learned from Covid-19 pandemic. Sustain. Cities Soc. 61, 102350. https:/ / doi.org/10.1016/j.scs.2020.102350

Mikolai, J., Keenan, K., Kulu, H., 2020. Intersecting household-level health and socioeconomic vulnerabilities and the COVID-19 crisis: an analysis from the UK. SSM-Popul. Health 12, 100628. Google Scholar

Miller, M.T., 2021. Do learning organizations learn? Higher education institutions and pandemic response strategies. Learn. Organ. https://doi.org/10.1108/TLO-092020-0159 
Moore, C., Greenland, S., 2017. Employment-driven online student attrition and the assessment policy divide: An Australian open-access higher education perspective. J. Open Flex. Distance Learn. 21, 52-62. Google Scholar

Myers, A., Berkowicz, J., 2015. The STEM shift: A guide for school leaders. Corwin Press.

Pappas, I.O., Giannakos, M.N., 2021. Rethinking Learning Design in IT Education During a Pandemic, in: Frontiers in Education. Frontiers, p. 103. https:/ / doi.org/10.3389/feduc.2021.652856

Pregowska, A., Masztalerz, K., Garlińska, M., Osial, M., 2021. A Worldwide Journey through Distance Education -From the Post Office to Virtual, Augmented and Mixed Realities, and Education during the COVID-19 Pandemic. Educ. Sci. 11, 118. https:// doi.org/10.3390/educsci11030118

Putra, P., Mizani, H., Basir, A., Muflihin, A., Aslan, A., 2020b. The Relevancy on Education Release Revolution 4.0 in Islamic Basic Education Perspective in Indonesia (An Analysis Study of Paulo Freire's Thought). Test Eng. Manag. 83, 10256-10263. Google Scholar

Qadir, J., Al-Fuqaha, A., 2020. A Student Primer on How to Thrive in Engineering Education during and beyond COVID-19. Educ. Sci. 10, 236. https://doi.org/10.3390/educsci10090236

Radanliev, P., De Roure, D., Walton, R., Van Kleek, M., Montalvo, R.M., Santos, O., Cannady, S., 2020. COVID-19 what have we learned? The rise of social machines and connected devices in pandemic management following the concepts of predictive, preventive and personalized medicine. EPMA J. 1-22.

Sakib, M.N., Butt, Z.A., Morita, P.P., Oremus, M., Fong, G.T., Hall, P.A., 2020. Considerations for an individual-level population notification system for pandemic response: a review and prototype. J. Med. Internet Res. 22, e19930. https:/ / doi.org/10.2196/19930

Scerri, M., Grech, V., 2020. To wear or not to wear? Adherence to face mask use during the COVID-19 and Spanish influenza pandemics. Early Hum. Dev. https:/ / dx.doi.org/10.1016\%2Fj.earlhumdev.2020.105253

Sgier, L., 2012. Qualitative data analysis. Initiat Gebert Ruf Stift 19, 19-21.

Siemens, G., 2013. Learning analytics: The emergence of a discipline. Am. Behav. Sci. 57, 1380-1400. Google Scholar

Soni, V.D., 2020. Global Impact of E-learning during COVID 19. Available SSRN 3630073. Google Scholar

SUDARMO, Nugraha, M.S., Mardhiah, R. I.liow, F.E., ASLAN, 2021. The Identification of Online Strategy Learning Results While Students Learn from Home During the Disruption of the COVID-19 Pandemic in Indonesia. J. Contemp. Issues Bus. Gov. 27, 1950-1956. https:/ / doi.org/10.47750/cibg.2021.27.02.205

Susilawati, S., Supriyatno, T., 2020. Online learning through WhatsApp group in improving learning motivation in the era and post pandemic COVID-19. J. Pendidik. Teori Penelit. Dan Pengemb. 5, 852-859. Google Scholar

Terranova-Barberio, M., Pawlowska, N., Dhawan, M., Moasser, M., Chien, A.J., Melisko, M.E., Rugo, H., Rahimi, R., Deal, T., Daud, A., 2020. Exhausted T cell signature predicts immunotherapy response in ER-positive breast cancer. Nat. Commun. 11, 1-10. https:/ / doi.org/10.1038/s41467-020-17414-y

Uebernickel, F., Thong, C., 2021. Contextualizing Design Thinking with Multiple Intelligences-The Global SUGAR Program as a Case. Google Scholar 
Van Deursen, A.J., Van Dijk, J.A., 2014. The digital divide shifts to differences in usage. New Media Soc. 16, 507-526. Google Scholar

Watermeyer, R., Crick, T., Knight, C., Goodall, J., 2021. COVID-19 and digital disruption in UK universities: Afflictions and affordances of emergency online migration. High. Educ. 81, 623-641. Google Scholar

Williamson, B., Eynon, R., Potter, J., 2020. Pandemic politics, pedagogies and practices: digital technologies and distance education during the coronavirus emergency. https:// doi.org/10.1080/17439884.2020.1761641

Yao, Z., van Velthoven, C.T., Nguyen, T.N., Goldy, J., Sedeno-Cortes, A.E., Baftizadeh, F., Bertagnolli, D., Casper, T., Chiang, M., Crichton, K., 2021. A taxonomy of transcriptomic cell types across the isocortex and hippocampal formation. Cell 184, 3222-3241. https:/ / doi.org/10.1016/j.cell.2021.04.021

Zulkarnain, Z., Heleni, S., Thahir, M., 2020. Digital literacy skills of math students through e-learning in COVID-19 era: a case study in Universitas Riau, in: Journal of Physics: Conference Series. IOP Publishing, p. 012015.

Zulman, D.M., Verghese, A., 2021. Virtual care, telemedicine visits, and real connection in the era of COVID-19: unforeseen opportunity in the face of adversity. JAMA 325, 437-438. doi:10.1001/jama.2020.27304

\section{Copyright Holder :}

(c) Abd. Basir., et al (2021)

First Publication Right :

(c) Jurnal Iqra' : Kajian Ilmu Pendidikan

This article is under:

(ㅇ)(1) (2) 